\title{
En ny offerposisjon? \\ Om styrkede rettigheter for fornærmede i straffesaker
}

\author{
Av Jane Dullum ${ }^{1}$
}

\begin{abstract}
A few decades ago, victims of domestic violence were relatively invisible in the penal process in Norway. Today, new penalties are implemented to fight domestic violence, and penalties have been increased. At the same time, there has been a growing critique of the use of legal strategies to fight domestic violence. The most profound critique has been that the penal system does not care for the victim. To protect the victim, victims' rights in the judicial process have thus been strengthened, e.g., the right to a lawyer; to attain information; to be present in the courtroom; to participate in the proceedings. The current article discusses the extent to which these new rights actually strengthen the position of victims of domestic violence.
\end{abstract}

\section{Innledning}

I et foredrag i Kriminalistforeningen i 1979 beskrev kvinnerettsjuristen Tove Stang Dahl kriminalitetsofrenes situasjon på denne måten: «Både kriminologien og kriminalpolitikken har langt på vei holdt ofrene for kriminalitet utenfor sitt interessefelt. Ofrene finnes ikke i kriminalstatistikken (...). En gang i blant kommer de til syne, men oftest som appendix til gjerningsmennene som har den egentlige kriminologiske interesse.» (her fra antologien «Pene piker haiker ikke», $1994 \mathrm{~s}$. 122 og 126)

Siden Stang Dahl skrev sin artikkel, har det imidlertid skjedd endringer i ofrenes stilling i straffesaker. Legalstrategi - forstått som bruk av (straffe)rettslige virkemidler - har blitt et relativt viktig virkemiddel for å bekjempe vold i nære relasjoner de siste tiårene. Tiltak i politiet, utvikling av et eget straffebud, en utvidelse av det straffbare samt skjerpede strafferammer er eksempler på slike legalstrategiske tiltak som er innført. ${ }^{2}$ Men denne utviklingen har ikke gått alene. I takt med straffereguleringen, har det blitt lovfestet rettigheter som tar sikte på å ivare-

* Title in English: A new position for the victim? On the strengthening of victims' rights in the penal process in Norway. 
ta ofrene i forbindelse med straffesaken. Et viktig skifte kom i 2008 - da ble det innført omfattende offerrettigheter i straffeprosessen, både i politiet og i domstolene. ${ }^{3}$ Formålet med denne artikkelen er å analysere disse rettighetene; hva de består i, og i hvilken grad de faktisk bidrar til å styrke ofre for vold i nære relasjoner.

Det er grunn til å fremheve at heller ikke denne utviklingen har foregått uten kritikk. Det har vært hevdet at styrkede rettigheter er et uttrykk for en samfunnsmessig utvikling der offerstatusen har ekspandert, og at denne ekspansjonen ikke er udelt positiv. Styrking av ofrene kan være negativt både for ofrene selv, for tiltalte i form av redusert rettssikkerhet, og samfunnsmessig i form av en mer repressiv straffepolitikk. I hvilken grad dette kan sies å være en treffende kritikk for Norges vedkommende, blir også diskutert i artikkelen.

\section{En rettssosiologisk innramming}

Artikkelens analytiske tilnærming knytter an til de rettssosiologiske debatter om rettsliggjøring og rettslig styring. Sentrale spørsmål i disse debattene er hvorvidt det er mulig å endre samfunnsmessige maktforhold og levekår ved hjelp av rettslige midler. Kan endringer i rettsregler virke reformerende? Spørsmålet kan synes overflødig - det store antallet lovendringer de siste tiårene skulle tilsi en stor tillit til lovers effektivitet (jfr. Hauge 2002). At lovendringer kan gi rettigheter som fører til endring, er også åpenbart, jfr. f.eks. store deler av velferdslovgivningen. Når lovgivningen har en slik påregnet virkning, kan man formulere det som at lovgivningens manifeste funksjoner oppfylles, slik Robert Merton fomulerte det i sitt berømte arbeid om lovgivningens manifeste og latente funksjoner fra 1949.

Men lovgivning kan også ha funksjoner som i liten grad er tilsiktet eller erkjent av lovgiver. Dette beskriver Merton som lovgivningens latente funksjoner faktiske virkninger på et samfunn som lovgiver ikke har forutsatt eller har klare forestillinger om. Latente funksjoner kan være av både positiv og negativ art. I den grad lovgivning har virkninger som skader eller bidrar til å svekke ulike sosiale ordninger, kan man med Merton formulere det som at lovgivningen har dysfunksjoner. Merton hevdet at sosiologiens oppgave er å avdekke slike utilsiktede konsekvenser av intensjonal handling. Det er først ved å oppdage slike sammenhenger at de kan korrigeres.

I norsk sammenheng er det særlig Vilhelm Aubert som har videreført Mertons analytiske rammeverk i sine rettssosiologiske analyser, bl.a. av norsk straffelovgivning. I boken «Om straffens sosiale funksjon» fra 1954, viser Aubert hvordan en av straffelovgivningens viktigste manifeste funksjoner - allmennprevensjonen - i liten grad fremmes gjennom den utformingen straffelovgivningen har. Men 
dette betyr ikke at straffelovgivningen ikke har funksjoner, men disse er av latent art. Lovgivningen kan f.eks. fungere som viktige symboler i et samfunn, de kan gi grupper en følelse av at deres interesser eller rettferdighetskrav er ivaretatt, og kan også opprettholde en tro på at lover blir håndhevet på en effektiv og rettferdig måte (Aubert 1954). I så måte kan lovgivning virke stabiliserende på et samfunn.

Det blir dermed et sentralt spørsmål om styrkede offerrettigheter har betydd en faktisk styrking av ofre for vold i nære relasjoner. Det er også viktig å undersøke mulige ikke-intenderte virkninger av lovgivningen. Nasjonalt og internasjonalt er pekt på en rekke latente virkninger av negativ art av en styrking av ofrenes stilling:

\section{Offerstatusens ambivalens}

En type negativ konsekvens som har vært påpekt, er at det er ambivalens knyttet til offerposisjonen. En sterkere offerorientering kan bidra til å gjenopprette verdighet og selvrespekt hos ofrene, men det kan også bidra til å befeste og opprettholde en offeridentitet; en identitet som fungerer kontrært i forhold til hva man har ment å oppnå med hjelpen. Denne ambivalensen ble tidlig tematisert av kvinnebevegelsen og kvinneforskningen. Introduksjonen av offerbegrepet var ment som et relasjonelt begrep; et begrep som fanget inn maktubalansen mellom utøver og offer, og retten til å være offer var en viktig kampsak (Ericsson 1993, Høigård 1993). Men offerbegrepet ble snart knyttet til individuelle egenskaper som passivitet, hjelpeløshet og objektstatus. En offeridentitet kan også være stigmatiserende og bidra til å fremme et negativt selvbilde. Dette frambrakte nye begreper, som «voldsutsatt» og «survivor»; begreper som skal overkomme offerbegrepets negative konnotasjoner.

\section{Offerrettigheter svekker siktedes rettigheter}

En annen kritikk som har vært rettet mot styrking av ofrenes stilling, er at dette svekker siktedes rettssikkerhet. Straffesaker oppstilles som en form for nullsumspill, der styrkede rettigheter for ofre fører til færre rettigheter for gjerningspersonen. Ved at fornærmede får delta mer, vil det svekke det upartiske og objektive ved straffeforfølgningen, er det hevdet (f.eks. Johnsen 2003). Dette er alvorlig, tatt $\mathrm{i}$ betraktning at straff er statens sterkeste maktmiddel mot borgerne.

\section{Offerrettigheter er straffedrivende}

Et tredje argument mot en styrking av offerets straffeprosessuelle stilling som har vært framført, er at dette er straffedrivende. Styrkede offerrettigheter, f.eks. ved at ofrene får delta i avgjørelsen av skyld- og straffespørsmålet, har bidratt til a "cul- 
ture of control” (Garland 2002). Sentrale pådrivere i en slik utvikling er den såkalte «offerindustrien» - organisasjoner som kjemper for kriminalitetsofres rettigheter - hvis krav igjen har blitt brukt politisk som argumenter for en strengere kriminalpolitikk. I nordisk sammenheng er det særlig den svenske kriminologen Henrik Tham som har rettet kritikk mot det han kaller for den framvoksende «offerdiskursen». Han viser til hvordan kriminalitetsofferet er blitt en stadig viktigere sosial figur i den svenske kriminalpolitiske debatten, og han mener dette har hatt en rekke negative konsekvenser, blant annet i form av straffeskjerpelser (Tham 2002).

\section{Offerrettigheter i en velferdsstatlig kontekst?}

I artikkelen vil jeg søke å belyse om og i hvilken grad styrkede offerrettigheter virker i tråd med lovgivers intensjoner. Har det skjedd endringer i den rettslige behandlingen av ofre for vold i nære relasjoner? Og har den nye lovgivningen bidratt til at ofrene kommer styrket gjennom rettsprosessen? Dette er artikkelens hovedtemaer. I hvilken grad rettighetene kan ha noen av de ovennevnte utilsiktede virkningene, som svekkelse av siktedes rettssikkerhet, er behandlet mer kortfattet. Dette er kompliserte spørsmål som vanskelig lar seg belyse empirisk. Men verdt å merke seg er at kritikken mot styrkede offerrettigheter ofte bygger på praksiser i anglo-amerikanske land - land med sosiokulturelle forhold og straffepraksiser som ligger fjernt fra de norske. Det er derfor nødvendig å spørre om kritikken treffer i en velferdsstatlig kontekst som den norske. Norge har langt lavere fangetall og lavere straffenivåer enn mange land det kunne være naturlig å sammenligne seg med (jfr. diskusjonene om «Nordic exceptionalism» i Ugelvik og Dullum 2012). Man kunne derfor kanskje forvente at utformingen av norske offerrettigheter ville adskille seg fra rettigheter i mer neo-liberale straffekulturer. Dette blir berørt avslutningsvis.

\section{Materiale og metodiske tilnærminger}

Artikkelen bygger på følgende materiale:

\section{Dokumentanalyser}

For det første bygger artikkelen på analyser av offentlige dokumenter og lovforarbeider. Disse dokumentene gir inntak til hvordan offerrettigheter er begrunnet og utformet. Særlig plass er viet forarbeidene til lovfestingen av nye prosessuelle rettigheter for fornærmede i 2008. Her er det såkalte Fornærmedeutvalgets innstilling - NOU 2006:10 «Fornærmede i straffeprosessen - nytt perspektiv og nye rettigheter» - helt sentral. Et stort antall høringsinstanser uttalte seg i høringsrun- 
den til innstillingen, bl.a. et utvalg domstoler, representanter for politi- og påtalemyndighet, forsvarere og «offerorganisasjoner». Jeg har innhentet og analysert høringsuttalelsene, de gir viktige innspill for å forstå den utformingen lovgivningen fikk.

\section{Intervju med straffesaksaktører}

Artikkelens andre empiriske inntak, består av kvalitative intervjuer med straffesaksaktører - 18 i alt. Utvalget består av aktører som har erfaring med fornærmede i straffesaker, og består av 3 dommere, 2 statsadvokater, 3 bistandsadvokater, 2 som praktiserer både som forsvarere og bistandsadvokater, 2 familievoldskoordinatorer i politiet og 6 representanter for ulike organisasjoner, vesentlig offerorganisasjoner og krisesentre. De intervjuede er fra ulike deler av landet. Temaet for intervjuene er deres syn på virkningene av de senere års offerstøttende tiltak, med særlig vekt på innføringen av nye prosessuelle rettigheter for fornærmede.

Grunnen til å velge et slikt materiale, er at det var en målsetting i dette prosjektet å få en viss breddeinnsikt i og -kunnskap om de offerstøttende tiltakenes virkninger, og det var viktig å velge et materiale som kunne være egnet til å belyse endring. Da framsto det som fornuftig å velge profesjonelle aktører som har lang erfaring, fra mange straffesaker, og som kjenner hele straffesaksprosessen, fra anmeldelse til henleggelse/domfellelse. Det kan rettes innsigelser mot at fornærmede selv ikke er gitt en sterkere stemme - det er deres interesser og opplevelser rettighetene skal verne om. Til det er å si at for de fleste ofre for straffbare handlinger er kontakt med rettsapparatet en engangshendelse. Ofre vil derfor ikke kunne si noe om eventuelle endringer. Dette betyr ikke at ikke ofrenes stemme trekkes inn i artikkelen, men det gjøres gjennom foreliggende studier. Det er foretatt flere studier som gir kunnskap om hva ofre for vold i nære relasjoner ønsker seg både av hjelpetiltak og av den rettslige prosessen. ${ }^{4}$ Ved å benytte disse studiene er det mulig å si noe om i hvilken grad de prosessuelle tiltakene som er innført, treffer ofrenes behov.

\section{Avgrensninger og begrepsbruk}

Hovedtemaet i denne artikkelen er å beskrive og analysere virkningen av prosessuelle rettigheter for ofre for vold i nære relasjoner. Det er grunn til å understreke at dette ikke på noen måte gir et dekkende bilde av norske offerrettigheter og tiltak. Norske offerrettigheter består av langt mer, både hjelpetiltak, beskyttelsestiltak, og kompensatoriske tiltak. For å nevne noen:

Hjelpetiltak for kvinner utsatt for vold i nære relasjoner har en helt sentral stilling i den norske utviklingen. Det mest markante tiltaket, er krisesentertilbudet. 
Med utspring i kvinnebevegelsen, ble det første norske krisesenteret etablert i Oslo i 1978. Fra 2010 fikk kommunene et lovpålagt ansvar for å ha et krisesentertilbud, som også skal inkludere menn. Som beskyttelsestiltak kan nevnes ordningen med besøksforbud fra $1994,{ }^{5}$ og kontaktforbud fra 2005. I 1988 ble kvinnemishandlingssakene undergitt ubetinget offentlig påtale. I 1998 ble de første stasjonære voldsalarmene tatt i bruk av politiet, og i 2004 ble en ordning med mobile voldsalarmer tatt i bruk. Adressesperre (såkalt «kode 6») og vitnebeskyttelsestiltak/fiktiv identitet er andre eksempler på tiltak som skal beskytte trusselutsatte. Et relativt nytt beskyttelsestiltak er risikovurderingsverktøyet SARA «Spousal Assault Risk Assessment Guide» - en sjekkliste utviklet til bruk for politi og rettsvesen for å vurdere fare for gjentakelse av partnervold. Kompensatoriske tiltak er en tredje gruppe offerstøttende tiltak, herunder voldsoffererstatningsordningen som fra 2008 ble utvidet til å omfatte ofre for vold i nære relasjoner. Det ligger mange spennende problemstillinger i analyser av slike tiltak, det har ikke vært mulig innen for denne artikkelens rammer.

Med vold i nære relasjoner sikter man gjerne til vold overfor nåværende eller tidligere partner, samt barn og pårørende (foreldre, besteforeldre) i rett opp- og nedstigende linje (jfr. strl. $2005 \S 284$ ). Denne artikkelen omhandler voksne fornærmede, barn som fornærmede reiser spesifikke problemstillinger som plassen ikke tillater å behandle. Fornærmede omtales som hun, utøver omtales som han. Dette betyr ikke at ikke kvinner kan være voldsutøvere og menn ofre, men betegnelsene er brukt pga. voldens helt spesifikke kjønnsretning. ${ }^{6}$ Fornærmede er straffeapparatets betegnelse for offeret. I denne artikkelen brukes offer og fornærmede om hverandre.

\section{Offerets stilling i straffeprosessen - en kort historikk}

I norsk rett har det i nyere tid vært et grunnperspektiv at straffesaken primært er et anliggende mellom staten og den siktede. Robberstad beskriver den historiske utviklingen slik: «I det store historiske perspektiv har utviklingen i hele Vesten gått fra privat til offentlig rettshåndhevelse, fra privat påtale til offentlig påtale. Den opprinnelige anklageren, fornærmede eller dennes slekt, er skjøvet til side og erstattet av staten som ledd i sentraliseringen av samfunnsmakten. Det opprinnelig likestilte forhold mellom to private parter er erstattet av den mektige staten mot den enslige siktede, med fornærmede som en svak aktør i periferien.» (Robberstad 2002, s. 2). ${ }^{7}$

I flere år har imidlertid ofrenes perifere stilling i egen straffesak vært problematisert. De har kun hatt vitnestatus i noe som i høyeste grad angår dem selv, de har ikke fått tilstrekkelig informasjon om - eller innsyn i - egen sak og, og de har 
hatt begrenset rett til deltakelse. Møtet med straffeapparatet kan også være en tung tilleggsbelastning for ofre for seksualisert vold og vold i nære relasjoner. Ett ankepunkt har vært at politiet gjør lite med denne typen saker; omfanget av henleggelser er stort. En annen kritikk har dreid seg om hvordan ofrene har blitt møtt av aktørene i strafferettspleien. Kontradiksjon er et grunnleggende prinsipp i straffesaker, og dette kan føre til at fornærmede blir utsatt for røff behandling fra rettens aktører. I tillegg har ufin opptreden, nærgående spørsmål om privatliv og seksuell vandel, mistenkeliggjøring osv. vært hyppige ankepunkter mot både politiets og domstolenes behandling av disse sakene. Denne kritikken har særlig rettet seg mot tiltaltes forsvarer. Lucia Zedner (2004) fanger opp disse ankepunktene ved å beskrive hvordan ofrene, ironisk nok, kan bli «... victims of the criminal process.» (s. 143). Straffesaksbehandlingen kan være ensbetydende med «sekundær viktimisering» «... whereby victims are as traumatized by their treatment within the criminal process as by the initial crime that triggered it. Failure to recognize the burdens placed upon victims can lead them to withdraw from the criminal process and limit its ability to pursue cases effectively.» (s. 143).

Denne kritikken er i Norge i økende grad tatt på alvor, og ulike departementsoppnevnte utvalg har hatt som mandat å komme med forslag til tiltak for å styrke ofrenes stilling. ${ }^{8}$ Et større skifte kom i 2008. Da ble det innført en rekke lovendringer som gir fornærmede (og etterlatte) utsatt for alvorlige voldsforbrytelser og seksuallovbrudd flere rettigheter både før, under og etter straffesaken. ${ }^{9}$ Jeg skal presentere hovedpunktene i disse endringene og begrunnelsene for dem.

\section{8: Nye rettigheter lovfestes}

\section{Rett til bistandsadvokat}

En helt sentral endring, er at ofre for vold i nære relasjoner fikk rett til bistandsadvokat. ${ }^{10}$ Dette etter at det fra flere hold lenge hadde vært fremmet krav om dette (Robberstad 2013). De første som fikk rett til bistandsadvokat, var fornærmede i voldtektssaker i 1981. Dette var begrunnet med den store belastningen etterforskning og rettsforhandlinger utgjorde for voldtektsofre. Fornærmedes forklaring var et viktig bevismiddel, og det var ofte nødvendig med særlig inngående avhør. Av hensyn til sakens opplysning var det grenser for hvor langt man kunne gå $\mathrm{i}$ å beskytte fornærmede mot ubehagelige avhør. Også for retten må saken opplyses best mulig slik at den kan treffe en riktig avgjørelse. Den fornærmede kunne derfor ha behov for en som utelukkende ivaretok hennes interesser, både $\mathrm{i}$ avhøret og i saken for øvrig.

Fornærmedeutvalget har en lignende begrunnelse for at fornærmede i saker om vold i nære relasjoner skal ha rett til bistandsadvokat. Fornærmedes trover- 
dighet ble trukket i tvil også i disse sakene, i tillegg ble det lagt vekt på at etterforskning og rettssak kunne være belastende for fornærmede (NOU 2006:10, s. 193). Bistandsadvokatens rolle er å ivareta fornærmedes interesser i forbindelse med etterforsking og hovedforhandling i saken. Bistandsadvokaten skal også gi slik annen hjelp og støtte som er naturlig og rimelig i forbindelse med saken (strprl § $107 \mathrm{c}$ ). «Annen hjelp og støtte» kan være å forklare rettsreglene for fornærmede, informere om hjelpetiltak og hjelpeapparatet for øvrig. Fornærmedeutvalget pekte på at for den mer mellommenneskelige typen av hjelp, er det «... viktig at advokaten holder seg innenfor advokatrollen» (s. 55), og viste til Robberstad (2003) som advarer mot at advokaten tar på seg en behandlerrolle som vedkommende ikke har forutsetning for. Utvalget fremhevet også at en slik sammenblanding av roller ble fremhevet av de fornærmede selv som uheldig og lite tillitvekkende.

Utvalget viste også til en kritikk på denne tiden om varierende kvalitet på arbeidet til bistandsadvokatene. For å styrke kvaliteten, foreslo de innført en fast bistandsadvokatordning ved de enkelte domstolene, lik den faste forsvarerordningen. Dette er nå innført.

De ofrene som har rett til bistandsadvokat ${ }^{11}$ har nå også fått flere andre prosessuelle rettigheter. Rettighetene har karakter av å være informasjons- og deltakerrettigheter. Reglene gir ofrene rett til informasjon og deltakelse før, under og etter straffesaken. I det følgende skal jeg presentere hovedtrekkene i disse rettighetene.

\section{Før anmeldelse}

Før anmeldelse, har ofrene nå rett til 3 timers kostnadsfri konsultasjon med en bistandsadvokat. Dette er innført fordi belastningen med en straffesak kan være stor, og man har sett det som viktig for offeret å ha en nøytral og profesjonell samtalepartner som også kan vurdere juridiske sider ved saken. Bistandsadvokatene skal ikke nødvendigvis oppfordre til anmeldelse.

\section{På etterforskningsstadiet}

Fornærmede har få̊t en rekke nye informasjonsrettigheter på etterforskningsstadiet. Fornærmede med bistandsadvokat skal nå holdes orientert om sakens utvikling og fremdrift (Påtaleinstruksen § 7-6). Så langt det er mulig skal også fornærmede med bistandsadvokat varsles før det holdes pressekonferanse eller opplysninger om saken offentliggjøres på annen måte. Politiet skal oppnevne en egen kontaktperson for fornærmede. Kontaktpersonen skal blant annet ha ansvaret for at fornærmede og etterlatte får den informasjonen de har krav på etter § 7-6. (På- 
taleinstruksen $\S 7 \mathrm{~A}-1$ ). Det er nå også tatt inn i påtaleinstruksen at politiet i avhør ikke skal stille spørsmål om fornærmedes tidligere seksuelle adferd med mindre det er av vesentlig betydning for saken. Eventuelle spørsmål må stilles på en så hensynsfull måte som mulig (§ 8-11). Dersom bistandsadvokaten anmoder om det, skal politiet gjennomføre et særskilt avhør av fornærmede for å belyse hvilke virkninger lovbruddet har hatt for henne (§8-9). Fornærmede har rett til dokumentinnsyn, og til å være tilstede i alle rettsmøter under etterforskningen. Det er bistandsadvokaten som skal varsles om rettsmøtene så langt det lar seg gjøre. Fornærmede har også rett til krav på underretning om påtalemyndighetens avgjørelse av påtalespørsmålet. Fornærmede har ikke rett til å bli hørt om sitt syn før påtalespørsmålet avgjøres. Men hun har rett til å klage på påtalemyndighetens avgjørelser. Videre skal påtalemyndigheten underrette fornærmede om at det er tatt ut tiltale, og om at fornærmede kan kreve å gjøre seg kjent med tiltalebeslutningen og sakens dokumenter.

Når det gjelder forberedelse til hovedforhandlingen, har fornærmede rett til å foreslå supplerende bevisførsel om straffekravet. Fornærmede har nå også fått en rett til en samtale med aktor før hovedforhandlingen. Fornærmedeutvalget mente dette kunne bidra til å skape trygghet og til å redusere belastningen ved å avgi forklaring i retten.

\section{Under hovedforhandlingen}

Tidligere var det slik at hovedforhandlingen ble innledet med opplesning av tiltalebeslutningen, deretter fikk aktor ordet til et kort innledningsforedrag, og forsvareren kunne få ordet til korte bemerkninger til det aktor hadde sagt. Etter dette fikk tiltalte forklare seg, og så fornærmede. Fornærmede hadde ikke rett til å være tilstede før hun selv hadde forklart seg, og hun fikk derfor ikke vite hva tiltalte hadde forklart, med mindre noen av aktørene gjenga det for henne. De deler av tiltaltes forklaring som ikke ble referert for fornærmede, kunne hun dermed ikke imøtegå.

Nå er reglene endret. Nå er det fornærmede som (som hovedregel) forklarer seg først, og fornærmede har fått rett til å være tilstede og å følge hele hovedforhandlingen. Hun får dermed også nå høre tiltaltes forklaring (strprl § 129). Dette er en stor endring som ble foreslått av Fornærmedeutvalget. Jeg skal si litt om deres begrunnelse:

Utvalget refererte at mange fornærmede opplevde det som urimelig at de selv var redusert til et vitne i egen sak, og at tiltalte hadde en sterkere prosessuell stilling enn dem selv i en sak som i høy grad berører dem og som de har inngående kunnskap om. Mange fornærmede i volds- og sedelighetssaker opplevde disse 
forskjellene som «... en fortsettelse av den maktesløshet de opplevde under overgrepssituasjonen, og at dette forsterker den traumatiserende virkningen av overgrepet. (...) ... mange fornærmede synes det er en ekstra belastning å måtte forklare seg uten å vite hva tiltalte har sagt i retten. En del fornærmede opplever det som urettferdig og krenkende at tiltalte gis anledning til å høre og kommentere deres forklaring i retten, mens de selv hverken har rett til å høre tiltaltes forklaring eller til å kommentere den. Noen fornærmede reagerer på at de først under prosedyren, eller etter at dom var avsagt, ble kjent med detaljer i tiltaltes forklaring i retten som de mener er uriktige. Det kan dreie seg om forhold som fornærmede ville ønsket å imøtegå i sin forklaring eller å få tilbakevist ved å stille spørsmål til tiltalte eller vitner. Særlig vanskelig oppleves situasjonen hvis de fornærmede i ettertid får vite at tiltalte har kommet med ufordelaktige opplysninger om dem for å svekke deres troverdighet som de ikke fikk anledning til å imøtegå.» (s. 150).

På denne bakgrunnen mente utvalget at det var en absolutt forutsetning for å styrke fornærmedes stilling, at fornærmede ble gitt anledning til å være tilstede under hele hovedforhandlingen. For at dette ikke skulle komme i konflikt med at vitner ikke skal overvære forhandlingene før egen forklaring, foreslo utvalget at fornærmede skal forklare seg før tiltalte. Dette kunne gi fornærmede økt trygghet, og bidra til økt forståelse av utfallet av saken. Det ble også pekt på at ordningen er slik i Sverige og Finland, uten at det synes å være innvendinger mot dette der.

Forslaget skapte imidlertid noe diskusjon i høringsrunden, og innsigelsene dreide seg om i hvilken grad dette ville gå ut over tiltaltes rettssikkerhet. Noe som kunne svekke tiltaltes situasjon var at det ville skape en «psykologisk slagside» som det kunne være tungt for tiltalte å rette opp når han først slipper til etter fornærmedes forklaring. Fornærmede ville kunne sette et «sterkere preg på saken», som en lagmannsrett uttalte i sin høringsuttalelse: «Når retten ikke kjenner noen av motargumentene, er den også mest åpen og lettest påvirkelig.»

Justisdepartementet mente imidlertid at endringen ville bidra til å styrke fornærmedes stilling uten at det svekket tiltaltes rettssikkerhet. Hans rett til kontradiksjon og eksaminasjon ble ikke svekket, og at fornærmede forklarer seg først, ville ikke svekke tiltaltes muligheter til å forsvarer seg mot anklagene. Departementet foreslo imidlertid at regelen skulle utformes slik at fornærmede med bistandsadvokat som hovedregel skal forklare seg først, og slik er det blitt (strprl. § 289 a). Dersom f.eks. tiltalte protesterer på rekkefølgen, må retten ta stilling til forklaringsrekkefølgen. 


\section{Rett til kommentarer under bevisførselen og sluttreplikk}

Også nytt i 2008, er at bistandsadvokaten til fornærmede nå har rett til å stille supplerende spørsmål til tiltalte, vitner og sakkyndige etter at aktor og forsvarer har avsluttet sin eksaminasjon (strprl. $§ 201$ a). Fornærmedeutvalgets flertall ${ }^{12}$ presiserte at det ikke var meningen at bistandsadvokaten skulle foreta noen full eksaminasjon. Retten til å stille spørsmål skulle begrenses til å gjelde spørsmål for å få frem forhold som ikke var kommet frem gjennom de øvrige aktørenes eksaminasjon. Fornærmede har også, på linje med tiltalte, fått rett til å uttale seg etter vitneforklaringer og opplesing av skriftlige bevis, og rett til sluttbemerkning (strprl. $\S \S 303$ og 304). Fornærmedeutvalgets begrunnelse for dette var at fornærmede som oftest kjenner saken veldig godt, og derfor har særlige forutsetninger for å bidra til sakens opplysning.

\section{Etter hovedforhandlingen}

Fornærmede har også fått rettigheter når det gjelder varsel om straffegjennomføring. Straffegjennomføringsloven benytter formuleringen om at «dersom det er av betydning for fornærmede eller dennes etterlatte» skal kriminalomsorgen varsle om tidspunktet for gjennomføring av straff utenfor fengsel (§16), tidspunktet for frigang (§20), tidspunktet for permisjon eller straffavbrudd (36), om domfelte unndrar seg gjennomføringen av fengselsstraff $(\S 40)$, om tidspunktet for løslatelse (§ 42) og om tidspunkt for prøveløslatelse (§ 45, Straffegjennomføringsloven av 2001). Fornærmedeutvalgets begrunnelse var at dette er opplysninger som er viktig for mange fornærmede i saker om vold, trusler og seksuallovbrudd. Noen kan være redde for represalier, andre for å påtreffe domfelte. De fornærmede kunne derfor ha behov for å ta forholdsregler mot å påtreffe domfelte. Utvalget foreslo ikke at fornærmede skulle få uttale seg på forhånd eller klage om avgjørelser om soning, og fornærmede har heller ikke fått noen slik rett.

\section{«The law in books» - en oppsummering}

Det har altså skjedd ganske store lovendringer når det gjelder fornærmedes straffeprosessuelle stilling de senere årene. Endringene er rettighetsorienterte - fornærmede har fått en økt rett til informasjon, til å bli hørt og til å delta - både under etterforskning, og under og etter selve hovedforhandlingen. Med disse endringene konstitueres fornærmede dermed som et rettighetssubjekt; en subjektposisjon som konstituerer offeret som en person med ønske om aktivitet og deltakelse, og som har en legitim rett til slik deltakelse. Dette er en subjektposisjon som ligger langt unna det å se offeret som stakkarslig og svakt, og som et passivt objekt. Fornærmedeutvalget skriver: «I et moderne samfunn er den enkeltes rett 
til innsyn i saker som angår en, til å kunne imøtegå opplysninger fra annet hold og til å gi uttrykk for sitt syn, ansett som grunnleggende forutsetninger for en god og betryggende saksbehandling. Dette gjelder i mange av livets forhold, men særlig i forholdet mellom den enkelte og myndighetene.» (NOU 2006:10, s. 16) Utvalget henviste til forvaltningsloven, lov om pasientrettigheter, saksbehandlingsreglene i barnevernlovgivningen, psykisk helsevernloven og andre lover som konkrete uttrykk for en slik tankegang, men mente at slike rettigheter først og fremst er grunnleggende i prosesslovgivningen. På denne bakgrunn kan det være naturlig å se innføringen av rettighetene i sammenheng med nye styringsformer i offentlig sektor, der brukermedvirkning, og rettighetsorientering er sentrale elementer. ${ }^{13}$

Men: Rettighetene skal utøves gjennom bistandsadvokaten. Fornærmedeutvalgets begrunnelse for dette, var at fornærmede har behov for rettshjelp for å kunne nyttiggjøre seg de nye rettighetene. Det ville også være en praktisk fordel for politiet, påtalemyndigheten og domstolene. I så måte er det ikke rettighetshaveren selv - fornærmede - som ivaretar rettighetene, men en advokat på vegne av henne. Dette reiser spørsmålet om kvaliteten på bistanden til advokatene, og om bistanden bidrar til en faktisk styrking av fornærmedes stilling. Dette kommer jeg tilbake til nedenfor. Men først:

Det kan være grunn til å påpeke hvilke rettigheter fornærmede ikke har fått. Dette har betydning i forhold til den internasjonale diskusjonen om en eventuell kollisjon mellom siktedes og fornærmedes rettigheter, og offerrettigheter som straffedrivende.

\section{Ikke fulle partsrettigheter}

Fornærmede har ikke fått fulle partsrettigheter. ${ }^{14}$ Det betyr blant annet at fornærmede ikke har noen innflytelse over straff- og skyldspørsmålet. Fornærmedeutvalget begrunnet dette slik: «Bruk av straff er samfunnets sterkeste virkemiddel for å unngå og å reagere mot uønsket adferd. Kriminalpolitikken bestemmes gjennom samfunnets valgte organer, og er et resultat av avveining av mange hensyn. Om det skal straffes, hva slags straff som bør idømmes og hvor streng den bør være, bør etter utvalgets fortsatt i hovedsak være statens anliggende. Påtalemyndigheten er best egnet til på samfunnets vegne å avgjøre om det faktiske og rettslige grunnlaget for å gå til straffesak foreligger. Strafforfølgning bør finne sted etter en objektiv og konsekvent linje, der hensynet til likebehandling må tillegges sterk vekt.» (s. 126). Lovgiver sluttet seg til dette, og det er dermed fremdeles slik at straffekravet avgjøres av domstolene i en sak med staten ved påtalemyndigheten og lovovertrederen som parter. ${ }^{15}$ 


\section{Ikke Victim impact statement}

Såkalt Victim impact statement er en mulighet for fornærmede og/eller etterlatte til å gi en sammenhengende forklaring om de virkningene de straffbare handlingen har hatt for dem. Dette er opprinnelig en amerikansk ordning. Fornærmedeutvalget foreslo at fornærmede og etterlatte skulle få en slik rett, og mange av høringsinstansene støttet dette. Bare ett politidistrikt gikk imot. Politidistriktet mente at en slik regel kunne virke noe anstrengt, og at innholdet burde kunne komme fram ved gode spørsmål fra retten og aktoratet når fornærmede ga sin vitneforklaring. Departementet var enig i dette, og foreslo ikke innført en slik regel for fornærmede, men kun for etterlatte som ikke skal vitne. Slik er også ordningen blitt (straffeprosesslovens $\S 303 a$ ).

Dette betyr at det som har vært rettet som en viktig kritikk mot styrkede fornærmederettigheter - at ofrene får delta i avgjørelsen av skyld- og straffespørsmålet, og at det dermed skjer en dreining i retning av at private interesser får spille inn i straffeforfølgningen - ikke er en relevant kritikk for Norges vedkommende. Om fornærmedes styrkede rettigheter kan ha innvirkning på siktedes situasjon på andre måter, kommer jeg tilbake til. Først skal jeg presentere hva de intervjuede straffesaksaktørene uttaler om i hvilken grad de styrkede rettighetene for fornærmede har fått betydning i praksis. Har det skjedd endringer i måten fornærmede blir ivaretatt på i domstolene og i politiet? Er det områder der rettighetene ikke har fått noen betydning? Hva kan være grunnene til det? Og er dette en utvikling som tjener ofrene? Dette er tema i det følgende.

\section{Har rettighetene fått betydning i praksis?}

De intervjuede mener det har skjedd endringer i straffesakskjeden, både når det gjelder fornærmedes deltakelse $\mathrm{i}$ egen sak, og behandlingen av de fornærmede $\mathrm{i}$ straffeapparatet. En bistandsadvokats uttalelse fanger inn dette: «Generelt vil jeg si at endringene i 2008 virkelig har hjulpet. Intensjonene med lovendringene er oppfylt. Fornærmede har fått en mye sterkere posisjon - fra anmeldelse til rettskraftig dom. Fornærmede får delta mye mer nå, situasjonen er forandret. Fornærmede har også fått en mer naturlig plass. Dommerne har en helt annen holdning, og som bistandsadvokat har jeg god kommunikasjon med forsvarerne. Det er også nyttig for fornærmede. Før 2008 var det mye tettere skott mellom forsvarer og bistandsadvokat.»

Men det er ikke på alle nivåer av straffeapparatet at rettighetene har fått betydning i praksis. Det er særlig i domstolene lovendringene har «satt seg», mener de intervjuede. En leder for en offerorganisasjon sier når jeg spør om lovendringene har hatt noen betydning for fornærmedes stilling under hovedforhandlingen. 
«Det er et godt spørsmål - for folk nå er det et sjokk at det ikke var på denne måten før, at det ikke alltid har vært sånn som det er nå. Nå er det en selvfølge at det skal være sånn. At fornærmede kan følge hele saken, sitte sammen med advokaten, vitne først, samtale med aktor på forhånd. Regelverket følges opp.» En lagdommer sier om de nye rettighetene for fornærmede under hovedforhandlingen: «Dette er blitt rettigheter - og de blir som regel ikke glemt av dommerne.»

De intervjuede mener også at det har skjedd nærmest en kulturendring i retten, en kulturendring som innebærer at fornærmede er bedre ivaretatt nå enn tidligere. I intervjuene er det ikke noe tema at dommere eller forsvarere spør ut ofrene på røffe måter, eller at de ikke tilstreber å gi ofrene en verdig behandling. Når det gjelder dommerne, sier en bistandsadvokat: «Det har skjedd en kulturendring blant dommerne. Særlig blant de yngre. De gamle holdningene, som 'kort skjørt', er på vei ut.» En slik endret kultur hos dommerne bekreftes av en annen bistandsadvokat. Hun sier: «Det har skjedd en endring også hos dommerne. De har blitt mer oppmerksomme på fornærmedes rettmessige plass. De er mer imøtekommende, også når det gjelder praktisk tilrettelegging. De er på tilbudssiden, de ønsker å hjelpe, og at det skal gå mest mulig smertefritt for fornærmede. Men det betyr ikke at de ikke er upartiske. Dette har med respekt å gjøre. Og det er kjempeviktig for fornærmede.»

Også de intervjuede dommerne mener det har skjedd endringer i domstolene. «Det har skjedd et paradigmeskifte», sier en sorenskriver. Og han fortsetter: «Tidligere var man ikke opptatt av fornærmedes stilling - domstolene levde sitt eget liv. Dommerne har også vært redde for 2008-endringene. Vi vil ikke ha noen private prosesser, og ikke forrykke balansen for mye. Så dommerne har vært motstrebende. Men nå har vi blitt flinkere til å ivareta både det fysiske og psykiske for offeret, nå er brukerperspektivet inne.»

Også forsvarerne har inntatt en mer respektfull holdning til fornærmede, mener de intervjuede. En representant for en offerorganisasjon sier: «Fornærmede og etterlatte har fått en selvfølgelig plass i retten, da må også forsvarerne skjerpe seg. Det handler også om folkeskikk.» Men at forsvarerne er mindre røffe, begrunnes også med at dårlig opptreden fra deres side taler mot klienten. En statsadvokat sier: «Forsvarerkulturen er på vei ut. Det går ut over klienten hvis de oppfører seg ubehøvlet. Dommerne blir irritert på bøller. Vi vet ikke hva som skjer på bakrommet, men det er ganske åpenbart at denne forsvarertypen skaper irritasjon.»

I den grad de intervjuede snakker om ubehøvlede forsvarere, er det som enkelttilfeller, eller som personavhengige unntak. En dommer sier: «Det hører til unntakene at aktørene oppfører seg ufint. Vi er mennesker. Og rettsrommet er et 
formelt rom. Det fører til at man oppfører seg. Forsvarerne skjønner også at dårlig oppførsel slår tilbake på klienten. Og dommerne reagerer. Men dette er personavhengig. Det er noen enkeltstående forsvarere som konsekvent oppfører seg ufint.»

\section{Om bistandsadvokatene}

Det er imidlertid ingen av de intervjuede som karakteriserer det å møte i retten som lettvint for fornærmede. Det å gå gjennom en rettssak karakteriseres fremdeles som svært krevende. Derfor har ofre for vold i nære relasjoner fătt rett til bistandsadvokat. Det har også vært et ønske om å heve kvaliteten på bistandsadvokatene gjennom å innføre en fast bistandsadvokatordning. Hva gjør så bistandsadvokatene? Hvordan oppfatter de sin rolle? I hvilken grad har det skjedd en styrking av bistandsadvokatordningen?

En bistandsadvokat framhever fornærmedes rett til å kunne ha samtaler med bistandsadvokat i tre timer med sikte på å vurdere anmeldelse, som en viktig lovendring. Det kan være forhold knyttet til fornærmedes eller familiens situasjon som kan gjøre at det er fornuftig å vente med en anmeldelse, mange kan trenge råd og veiledning om hva det vil si å anmelde et forhold til politiet. Men ordningen er for lite brukt, mener hun, særlig av politiet.

Ellers ser bistandsadvokatene det som sin hovedoppgave å delta under avhør og i hovedforhandlingen, samt å informere klienten om de ulike stadiene i rettsprosessen. En bistandsadvokat sier: «Min viktigste rolle er å informere hele veien, i alle stadier. Det kan avhjelpe hele prosessen. Hvis fornærmede forstår, er det enklere å gå videre.»

De ser det også som sin oppgave å forberede klienten på belastningen ved å møte i retten. En bistandsadvokat sier: «Det er en enorm belastning å møte i retten. Det er mange fornærmede som blir kjørt hardt i dag også. Så det er ikke noe glansbilde. Men fornærmede må forberedes på tiltalte, og på forklaringen sin. Dette er bistandsadvokatens jobb. Gjennom at hun har tilgang til saksdokumentene, vet hun mye på forhånd om hva som vil komme. F.eks. det at han sier at hun er gal osv. Men jeg tenker ikke at det er reviktimisering som skjer, heller at det kan være bra at hun hører på ham. Og så kommer dommen, og det kan være godt å få erklæringen om at hun blir trodd, og at domstolen ikke har hørt på hans uttalelser om henne.»

En annen bistandsadvokat sier: «En sentral oppgave for bistandsadvokaten er å forberede klienten på å møte i retten. Retten til kontradiksjon er en grunnleggende rettighet. Fornærmede må tåle å høre siktedes forklaring, det er en konsekvens av å anmelde. Men det er jo ikke sånn at man må være i retten og overhøre hans forklaring, det er helt frivillig å være der. Det er ingen deltakerplikt.» Og en 
annen bistandsadvokat sier: «Det er en rett til å være tilstede, ikke en plikt. Jeg tar en vurdering på det. Vil det gjøre for vondt? Så jeg tar en vurdering på om hun kan takle det. Noen vil det sterkt, de vil se han inn i øynene. Når hun er tilstede, er det også vanskeligere for ham å lyve. Ikke minst er det viktig å høre vitnene. De er ofte bekjente. Da er det bra å være tilstede og høre hva de sier, da får man mer kontroll på saken.»

Bistandsadvokatene understreker også viktigheten av å ha et bevisst forhold til rollen, noe som også er framhevet i lovforarbeidene: «Vi er ikke terapeuter», som en bistandsadvokat sier det. En forbedring av kvaliteten på bistandsadvokatene fremheves også som en sentral endring de senere årene, og at særlig innføringen av ordningen med faste bistandsadvokater har bidratt til dette. En bistandsadvokat sier: «Ordningen med faste bistandsadvokater har bidratt til å heve nivået. Også Advokatforeningens etterutdanningskurs for bistandsadvokater har vært viktige. Det har blitt et høyere nivå på kursene, og derav et høyere nivå på advokatene.»

Men det er også kritiske røster til bistandsadvokatordningen. En dommer mener at rollen som bistandsadvokat er uavklart: «Noen er på grensen av sjelesørgere. Men er de kvalifisert for det? Bør ikke dette være hjelpeapparatets rolle? Det mangler en juridisk avklaring av hva som skal være bistandsadvokatens rolle.» Så også når det gjelder bistandsadvokatene hevder de intervjuede at hovedtrekket er at det har skjedd en styrking av advokatene, men at det er enkeltadvokater som utfordrer dette generelle bildet.

\section{Politiet}

Når det gjelder rettigheter som er innført på etterforskningsnivå, mener de intervjuede at det er betydelig større variasjon i hvordan politiet ivaretar fornærmede i saker om vold i nære relasjoner. Tidligere studier har vist til dels stor misnøye med politiets arbeid (f.eks. Grøvdal 2012). Et funn i dette materialet er at politiet har blitt bedre til å informere, og til å ta kvinner på alvor. En bistandsadvokat sier: «Informasjonen er bedre enn før. Politiet har innarbeidet visse rutiner.» Flere trekker også fram enkelteksempler på gode praksiser. En bistandsadvokat viste f.eks. til et nylig avhør med en fornærmet der avhører hadde forklart kvinnen bakgrunnen for at hun stilte de spørsmålene hun stilte, og som følge av dette hadde kvinnen kommet seg ganske helstøpt gjennom avhøret. Men hun nevner også en annen politistasjon som hun mener har dårlig rykte på seg i forhold til anmeldelse, og der ofre blir dårlig ivaretatt.

Og dette er et gjennomgående trekk i dette materialet: Det er de varierende praksisene hos politiet som trekkes fram. En leder for en offerorganisasjon peker på store forskjeller på landsbasis i politiets behandling av sakene. I de større bye- 
ne har politiet rutiner mener hun, men gir flere eksempler på mindre steder der politiet ikke har gitt informasjon, og der også bistandsadvokatene i liten grad har fulgt opp saken overfor politiet. På den måten blir fornærmede overlatt til seg selv: «Det er stor forskjell på by og land. I de større byene er det gode bistandsadvokater. I en del mindre byer er det ingen ting, og ofte dårlige advokater. Noen ganger begynner politiet avhørene uten at bistandsadvokaten er tilstede. Mange kjenner ikke rettighetene sine, og dessuten: Hva gir politiet ut av informasjon? Det varierer veldig.»

De intervjuede gir også eksempler på prosessuelle rettigheter under etterforskningen som er innført, men som kun er papirrettigheter, eller som rettigheter som har liten betydning. En bistandsadvokat sier f.eks. at rettigheten om en fast kontaktperson i politiet, ikke fungerer. Hun er forøvrig tvilende til om det er noen relevant rettighet, hun har erfart at kontaktpersonen ikke vet alt, og at det er bedre å ha kontakt med etterforskeren.

I dette materialet framstår det som om politiets ivaretagelse av fornærmedes rettigheter er både steds- og personavhengig. Dette er i tråd med funn i Geir Aas sin evaluering av politiets arbeid med vold i nære relasjoner. Hans intervjuer med ansatte og brukere ved krisesentre dokumenterer en rekke fortellinger om et politi som er til hjelp og støtte for voldutsatte, og at det har skjedd betydelige forbedringer av politiarbeidet de senere årene. Men samtidig er det rikelig med eksempler på det motsatte. Også Aas konkluderer dermed med at den hjelpen man får fra politiet, i stor grad er «... person- og stedsavhengig.» (2014, s. 129).

\section{Betydningen for siktede?}

Som nevnt innledningsvis, har et ankepunkt mot å styrke fornærmedes rettigheter, vært at dette svekker siktedes rettssikkerhet. Fornærmedeutvalget tok opp denne problemstillingen, og avviste at det å gi fornærmede innsyn, deltakelse og muligheter til å bidra med informasjon, skulle svekke tiltalte på noen måte: «Utvalget understreker at det gjennomgående er en forfeilet problemstilling når det argumenteres for at man må finne den rette «balanse» mellom siktede og fornærmede. En slik tankegang forutsetter at siktedes posisjon svekkes hvis fornærmede gis økte rettigheter. Forholdet er imidlertid oftest at fornærmede kan gis rettigheter som siktede allerede har. Det reduserer selvsagt ikke siktedes stilling.» (NOU 2006:10, s. 17). I høringsrunden var det imidlertid to høringsinstanser som var kritiske. Det var Forsvarergruppen av 1977, og en av lagmannsrettene. Forsvarergruppen mente bl.a. at styrkede rettigheter for fornærmede ville føre til svekkede rettssikkerhetsgarantier for siktede. Ikke alle fornærmede snakker sant, påpekte gruppen, og slike «falske fornærmede» hadde ingen legitim interesse $\mathrm{i}$ 
straffesaken som rettsreglene burde beskytte. Departementet avviste imidlertid dette, og argumenterte med at «fornærmede» er en rent prosessuell betegnelse, og at det heller ikke ellers i prosessen er slik at prosessuelle rettigheter begrenses til dem man på forhånd mener også har materiell rett (Ot.prp. nr. 11 2007-2008, s. 24).

Det de intervjuede i denne undersøkelsen er samstemte om, er at det kan oppleves som skjevt når det $\mathrm{i}$ en sak er mange fornærmede og mange bistandsadvokater, men én tiltalt med sin forsvarer. Aktørene er også opptatt av at bistandsadvokatene ikke må gå inn i en rolle som hjelpeaktor. De mener dette kan forrykke balansen mellom fornærmede og utøver. En statsadvokat sier: «Bistandsadvokatene avlaster oss, vi er et team. De kan trygge klientene på alle ting. Men de må skjønne sin rolle, ellers går det utover tiltalte. Noen går inn på vår rolle, og driver utspørring. Det går ikke, det blir en ujevn maktbalanse 2 mot 1.» En lagdommer mener imidlertid at her har det skjedd en endring til det bedre: «De fleste bistandsadvokatene er edruelige i retten. Det var verre i begynnelsen, da var det noen som gikk inn som hjelpeaktorer. Vi ser ikke det så mye nå. Nå er jeg heller slått av hvor passive de er.»

Ellers er de intervjuedes holdning til spørsmålene om fornærmederettighetene går ut over siktedes rettssikkerhet, preget av deres ulike posisjon i straffesaken. Forsvarerne er kritiske. En forsvarer synes f.eks. det er greit at fornærmede har fått anledning til å følge hele saken, men er svært kritisk til at fornærmede nå forklarer seg før tiltalte: «Det er feil. Det er en tiltale som er tatt ut, og da bør tiltalte forklare seg først. Hvis det hadde vært erstatningsspørsmålet det hadde vært snakk om, er det naturlig at det er fornærmede som forklarer seg først. Jeg liker ikke at man legger premisser. Dette sender også uheldige signaler til meddommerne. Man har laget en hybrid, og det synes jeg er feil.»

Men hovedtrekket i materialet er at det at fornærmede får delta mer, styrker sakens opplysning, og at det også kan styrke siktede. En bistandsadvokat sier: «Det at fornærmede har fått flere rettigheter i forhold til deltakelse, gjør at saken blir bedre opplyst. Og det er også en styrke for tiltalte. Det er heller ikke alle fornærmede som snakker sant. Det er også en fordel for tiltalte at fornærmede forklarer seg først, da vet han hva som kommer. Så rekkefølgen på forklaringen kan slå begge veier.» En lagdommer sier: «Vi (dvs. denne lagmannsretten, min tilf.) var skeptiske til endringene som ble foreslått i Fornærmedeutvalget av hensyn til tiltaltes rettssikkerhet. Men balansen er ikke forrykket, det fungerer greit. Endringene kan til og med fungere greit for tiltalte, nå får tiltalte anledning til å svare på det fornærmede har uttalt.» 
En tingrettsdommer inntar et mellomstandpunkt: «Det er ulike meninger om dette. Det å løfte fram fornærmede er positivt. Nå kan hun være tilstede under hele rettssaken, og hun får høre hva tiltalte har å si. Fornærmedes forklaring er ofte utgangspunktet for historien, og tiltalte kan svare. Det kan være en pedagogisk god ting for retten. Og dette er ikke nødvendigvis negativt for siktede heller. Siktede kan tilpasse seg hennes forklaring. Han har lest politiforklaringene, men det gir ikke den samme muligheten for tilpasning som når han skal forklare seg rett etter henne. Det er nødvendigvis ikke sånn at hun setter agendaen, det er ikke nødvendigvis en fordel å forklare seg først. Det kan være en fordel å være sist også. Dette er kompliserte mekanismer, også psykologisk. Så det er vanskelig å vite hvem som tjener og hvem som taper på dette.»

Med dette skal jeg forlate intervjumaterialet, og avslutningsvis samle trådene. Hvor stor betydning har de nye fornærmederettighetene fătt for ofrenes stilling $\mathrm{i}$ straffesaker? Hvilke mulige uintenderte virkninger har de nye rettighetene? Disse spørsmålene skal diskuteres avslutningsvis.

\section{Om lovgivningens virkninger: Oppsummering og diskusjon}

Det ser ut til at den styrkingen av fornærmedes straffeprosessuelle stilling som ble lovfestet i 2008, har hatt virkninger. Det er særlig på domstolsnivå lovendringene ser ut til å ha slått inn. De fornærmede får nå følge hele saken hvis de ønsker det, og de har fătt en økt rett til deltakelse. Det ser ut til at det har skjedd en kultur- eller holdningsendring til fornærmede hos straffesaksaktørene i retten, informantene i denne studien forteller om en respektfull behandling av ofrene i rettssalen. De mener også at fornærmede er tryggere, bedre ivaretatt og bedre forberedt til straffesaken enn før. Dette siste skyldes særlig bistandsadvokatene, som nå har blitt en rettighet for ofre for vold i nære relasjoner. Bistandsadvokatene framholdes også som mer profesjonelle enn tidligere. Ikke så å forstå at en rettssak fremdeles ikke er en stor påkjenning for fornærmede, i dette materiale er det ingen som underspiller hvor krevende det er for fornærmede å gjennomføre en hovedforhandling. Men de framhever at selve straffesaken har fătt et mer humant tilsnitt.

Særlig de nye deltakerrettighetene, som retten til å være tilstede under hele hovedforhandlingen, fremholdes som en rettighet som bidrar til å gjenopprette selvrespekt og heling hos ofrene. Det vi si at det skjer det motsatte av en befesting av offerrollen. Som en bistandsadvokat sier: «Det er kjempeviktig at man făr delta i egen sak. Det er også viktig i et lengre perspektiv, det er en del av det å komme seg videre. Man blir gitt en ny styrke til å gå videre, og det bidrar til helingsprosessen.» 
I politiet ser det ut til å være mer varierende praksiser når det gjelder ivaretakelse av fornærmedes rettigheter. Det sies at situasjonen har bedret seg, at politiet tar sakene mer på alvor, og at de behandler fornærmede på en ordentlig måte. Men det sies også at det er svært varierende praksiser i politiet når det gjelder ivaretakelse av fornærmedes rettigheter.

Det ligger interessante forskningsspørsmål i å følge opp hvorfor det er slik og hvorfor dette over tid ser ut til å være et gjennomgående trekk ved politiets arbeid (jfr. også Aas 2014). Her skal noe antydes: Hvor mye ressurser og kompetanse som settes inn på etterforskning og iretteføring av saker om vold i nære relasjoner, kan variere mellom politidistriktene. Noen steder kan det være lite erfarne etterforskere som blir satt på disse sakene, og det kan bli dårlig kvalitet på etterforskningen. Påtalejuristene kan være overbelastet, og det kan være stor utskifting blant dem. Men også trekk ved politikulturen kan spille inn. En familievoldskoordinator tar opp hva som har prioritet og status i hans politidistrikt: Narkotika, organisert kriminalitet og beredskap. Det er en sterk «macho-kultur» i politiet, mener han, forbildene for unge politifolk er de som jobber med våpen og beredskap. Etterforskningen av saker om vold i nære relasjoner, derimot, har lav status. Arbeidet er kvinnedominert og det er kvinner og barn som er ofre, dette skaper ikke status, og dermed kanaliseres lite ressurser til disse områdene.

Et tredje forhold som kan spille inn, er mål- og resultatsstyringssystemet i politiet. En sterk vekt på oppklaringsprosent og saksbehandlingstid, kan bidra til at vold i nære relasjoner får lav prioritet. «Oppklaringsprosent og de øvrige måleparameterne samsvarer ikke med det som er problemene i vold i nære relasjoner», mener en familievoldskoordinator. Her trenger fornærmede mer tid, man må ha fornærmede med i beslutningsprosessen, noen ganger må man avhøre fornærmede flere ganger. Ofte kreves også samhandling med andre instanser. Dette er viktig arbeid for fornærmede, men det måles ikke, og dette kan bidra til at disse sakene blir nedprioritert.

\section{Rettighetenes symbolfunksjoner?}

Det at rettighetene særlig ser ut til å ha hatt sitt nedslag i domstolenes behandling av saker om vold i nære relasjoner, betyr at rettighetene omfatter et lite antall fornærmede. For det er få saker som kommer til domstolene, de fleste sakene om vold i nære relasjoner blir henlagt. Slik har det vært, og slik er det fremdeles. Det har vært en kraftig økning i antall anmeldte $\S 219$-saker ${ }^{16}$ de senere årene (i perioden 2006 - 2011 skjedde en mangedobling (fra i underkant av 500 til i underkant av 2500 anmeldelser) (Aas 2013). Men 70\% av alle ferdig etterforskede $\S$ 219-saker i 2010 ble henlagt, i 23\% av sakene ble det tatt ut tiltale (s.st.) I 2014 
ble det tatt ut tiltale i $21 \%$ av de 2279 etterforskede sakene om mishandling i familieforhold, mens andelen var $28 \%$ i saker om grov mishandling (Kriminalstatistikken 2014, tabell 2).

Det at så mange saker henlegges, betyr for det første at situasjonen langt fra kan beskrives dithen at det har skjedd en kraftig offerdreining i straffeapparatet. Det skjer lite med flertallet av det økende antallet anmeldelser. ${ }^{17}$

For det andre betyr det at de nye fornærmederettighetene får en viss symbolsk karakter. Ved at mange saker henlegges, får rettighetene et smalt nedslagsfelt. En av høringsinstansene til Fornærmedeutvalget - et statsadvokatembete - advarte mot nettopp dette: «Vi er enige $\mathrm{i}$ at fornærmedes prosessuelle stilling i straffesaker trenger en gjennomgående debatt. (...) Den viktigste reformen for å forbedre fornærmedes stilling i straffeprosessen vil være å legge forholdene til rette for at straffesakene gjennomføres raskt, at kvaliteten på etterforskning, påtalearbeid og rettergangsføring er høy og at gjerningsmennene får en adekvat reaksjon. De objektive interessene til de fornærmede bør settes foran mer symbolske rettigheter av minimal betydning som bare et svært lite mindretall av de fornærmede antas vil komme til å benytte seg av.»

Det symbolske understrekes ytterligere av at det som framheves som det største problemet ved straffeapparatets behandling av saker om vold i nære relasjoner ikke er løst gjennom den nye rettighetsfestingen: Lang saksbehandlingstid. Mange saker tar svært lang tid, noe som utgjør den største belastningen for de fornærmede, fremhever de intervjuede i denne undersøkelsen. Det er unison enighet om dette. En bistandsadvokat sier: «Noen saker er ille, andre er helt forferdelige. Det er den største utfordringen i disse sakene.» Og en annen bistandsadvokat sier: «Etterforskningen tar alt for lang tid, det går for sakte. Det er der skoen trykker, og der de virkelig kan gjøre en forbedring. Sakene bør bli raskere ferdig, også hos påtalejuristene. Sakene blir for gamle, og så får den dømte strafferabatt. Mange fornærmede reagerer på det. Og livet blir satt på vent så lenge straffesaken pågår. Når har jeg ventet så og så lenge ... Det virker ikke som om politiet greier å ta dette inn over seg. De fornærmede tror ikke at de blir tatt på alvor når saken ligger i mange måneder uten at politiet gjør noe. Politiet ser ikke dette. Tidsaspektet er spesielt uheldig i denne typen saker. For fornærmede beveger ting seg i en syklus. Sårene gror, kanskje har man barn, man mister motet, man ser ikke viktigheten av en straffesak. Interessen dabber av. Og det kan skje at de lar de gamle følelsene for mannen ta overhånd. Dette er ikke heldig i denne typen saker. Påtalemyndigheten ville også profitert på en fornærmet som er i kamphumør.»

De intervjuede sier at livet til fornærmede blir satt «på vent» i tiden fra anmeldelse til saken er avgjort, og at dette bidrar til å holde fornærmede fast i offerrol- 
len i lang tid (jfr. også Grøvdal 2012). Og som en forsvarer også fremhever: Her har fornærmede og tiltalte sammenfallende interesser - «Ventetiden er forferdelig for alle», som hun sier det.

Det er dermed grunn til å påpeke det fremdeles er store utfordringer når det gjelder straffesaksbehandlingen av saker om vold i nære relasjoner. Men samtidig er det grunn til ikke å underspille betydningen av de innførte fornærmederettighetene. En stadig tilbakevendende kritikk mot bruk av legalstrategi i saker om vold i nære relasjoner, har vært den tilleggsbelastningen det har vært for ofrene å møte i domstolen. At man ikke har fått delta i egen sak, og at man til dels har blitt dårlig behandlet av rettens aktører, har ført til en stor skepsis til bruk av legalstrategi i disse sakene (Grøvdal 2012, Skjørten 2002). Nå får fornærmede delta mer, og hun har fătt en mer naturlig plass i rettssalen. Dette er en betydningsfull endring, som på sikt også kan tenkes å gi en større legitimitet til straffeapparatets behandling av disse sakene.

Helt avslutningsvis skal jeg kort kommentere i hvilken grad rettighetene kan ha mulige latente virkninger av uønsket art.

\section{Er offerrettighetene straffedrivende?}

Som vist, har ikke fornærmede fått fulle partsrettigheter. De får dermed ikke uttale seg om skyld- og straffespørsmålet, de kan ikke anke over skyld- eller straffespørsmålet, og de får ikke avgi noe særskilt Victim impact statement. Dette viser at en kritikk om at ofrenes deltakelse i straffesaken skulle bidra til straffeskjerpelser ved at de får uttale seg om skyld- og straffespørsmålet, ikke treffer den norske konteksten. ${ }^{18}$ Forøvrig bygger en slik kritikk på en forestilling om det hevngjerrige offer, og et premiss om at ofre skulle være mer straffeivrige enn staten. Dette er i liten grad dokumentert, ofte forholder det seg vel motsatt spesielt når det gjelder vold i nære relasjoner. F.eks. er det jo få som ønsker en involvering av straffeapparatet i det hele tatt, og mange ofre for vold i nære relasjoner ønsker ikke gjerningsmannen straffet. ${ }^{19}$ De ønsker en slutt på volden, og å bli tatt på alvor og bli møtt med respekt, men ikke at gjerningsmannen får en lang fengselsstraff. «The myth of the vengeful victim», kaller Herman (2005) ideen om ofrenes såkalte straffeivrighet. Hun beskriver det slik: "The presumption that the state will be more dispassionate, fair, and less punitive than the victim is rarely questioned. This presumption seems to be based in a deep distrust of the victim's anger." (2005, s. 576). Hun mener også at “... the general societal distrust of victims' emotions is so reflexive and deep that it amounts to a taboo." (s. 577).

I de senere års internasjonale forsøk med therapeutic jurisprudence er det også gjort funn som viser at «... the nature of an IPV (dvs. intimate partner violence, 
min tilf.) victim's experience in the court system as a whole may be equally ore more important to her than what happens at the end of it.» (Bennett Cattaneo and Goodman 2010, p. 483).

\section{I konflikt med siktedes rettssikkerhet?}

Hva har så de offerrettighetene betydd for siktede? Det er vanskelig å si noe sikkert om i hvilken grad styrkede fornærmederettigheter kommer i konflikt med siktedes rettssikkerhet, dette er et vanskelig målbart spørsmål. Her er nok også aktørenes posisjon i straffeapparatet (dommer, forsvarer, aktor eller bistandsadvokat) avgjørende for hvilket svar man får, og det er vel ikke mulig å si om det er noen som har mer «rett» enn andre. I dette materialet er det imidlertid flere som argumenterer for at det at fornærmede kan delta mer, bidrar til at sakene blir bedre opplyst, og ikke til en svekkelse av siktedes rettssikkerhet. At fornærmede har fătt rett til bistandsadvokat skulle bidra til en ubalanse, er heller ikke en slutning som kan trekkes på grunnlag av dette materialet. Unntaket er hvis bistandsadvokatene inntar en posisjon som en slags «hjelpeaktor», og hvis det er mange fornærmede og mange bistandsadvokater og én siktet.

Ellers kan det her være grunn til å sitere hvordan Fornærmedeutvalget argumenterte mot synspunktet om at økte rettigheter til fornærmede skulle gi en urettferdig to-mot-en-situasjon. Utvalget mente at denne tankegangen hadde sitt utspring $i$ «... en nokså uklar sammenligning med sportsverden hvor det er viktig at det er like mange på hvert lag for at konkurransen skal bli rettferdig. I en offentlig straffesak er helt andre hensyn dominerende. I straffesaker er formålet å finne frem til det riktige resultat under ivaretakelse av alle rettssikkerhetsgarantier. Det er noe ganske annet enn en sportsbegivenhet hvor det interessante er å se hvem som vinner. I en straffesak er det ingen «vinnere».» (NOU 2006:10, s. 17).

\section{Noter}

1. Jane Dullum er forsker ved Velferdsforskningsinstituttet NOVA ved Høgskolen i Oslo og Akershus. Artikkelen springer ut av prosjektet «Offerstøttende og -beskyttende tiltak i rettsprosessen» som er en del av NOVAs fem-årige forskningsprogram om vold i nære relasjoner finansiert av Justis- og beredskapsdepartementet. Takk til Kjersti Ericsson og Ragnhild Hennum for kommentarer til artikkelen.

2. Utviklingen av strafferettslige virkemidler for å bekjempe vold i nære relasjoner blir nærmere beskrevet og analysert i Bakketeig og Dullum forthcoming.

3. Ett av utgangspunktene for endringene, var erkjennelsen av fornærmedes ulike straffeprosessuelle stilling i de nordiske landene på denne tiden. I utredningen «Kontradiksjon og verdighet» viste Anne Robberstad hvordan det gikk et skille mellom de vestnordiske land (Danmark/Norge/Island), og de østnordiske (Sverige/Finland). I Sverige og Finland hadde 
eksempelvis fornærmede mulighet til å oppnå full partsstilling i straffesaken, mens i Norge, Danmark og Island hadde fornærmede hovedsakelig status som et vitne (Robberstad 2002). Finland framsto som det mest fornærmede-vennlige landet i Norden. Det ligger en interessant oppgave i å undersøke hva som skiller og hva som forener de nordiske landene på dette området i dag, denne artikkelen gir kun rom for å behandle reglene i de øvrige nordiske landene helt kortfattet.

4. S f.eks. Aas 2014 som har intervjuet 21 voldsutsatte kvinner om den rettslige prosessen, Grøvdal 2012 som har intervjuet 8 voldsutsatte kvinners møte med straffeapparatet. Det foreligger også internasjonale studier som gir slik informasjon (se f.eks. Wemmers metastudie fra 2009).

5. Ordningen ble importert fra Sverige, som innførte den i 1988 (Robberstad 2002).

6. I en forekomststudie fra NKVTS i 2014, kommer det f.eks. fram at kvinner er betydelig mer utsatt enn menn for seksuelle overgrep, og det er nesten utelukkende menn som er overgriper i seksuelle overgrep mot kvinner. Menn sto også for ca. to tredeler av de seksuelle overgrepene mot menn. Menn og kvinner var omtrent like utsatt for mindre alvorlig partnervold, mens det i all hovedsak var kvinner som var utsatt for den alvorlige partnervolden. Den samlede voldsbelastningen for kvinner var vesentlig større enn for menn i antall voldskategorier de hadde opplevd (Thoresen og Hjemdal (red.) 2014, s. 129).

7. Vel og merke, som Grothe Nielsen og Snare påpeker: Tidligere tiders «gyldne tider» for ofrene, handlet om rike og maktfulle menn, ikke økonomisk ubemidlede eller menn uten makt. Og heller ikke barn og kvinner. De skriver: «Inden for husstanden var de undergivet det mandlige overhoveds tugt, revselse og seksuelle forgodtbefindende. (...) Kvinder var under værgemål af en far, bror eller ægtemand og helt uden selvstændig rolle i offersituationer.» (1998, s. 19).

8. Et tidlig forslag kom i NOU 1992:16: «Sterkere vern og økt støtte for kriminalitetsofre». I 2002 kom Anne Robberstads utredning «Kontradiksjon og verdighet». Utredningen møtte til dels sterk motstand på noen punkter (se f.eks. Johnsen 2003) og forslagene førte i liten grad frem.

9. Bl.a. Lov 7. mars $2008 \mathrm{nr} .5$ om endringer i straffeprosessloven mv. (styrket stilling for fornærmede og etterlatte). Loven trådte i kraft 1. juli 2008. I 2007 vedtok også Danmark endringer i ofrenes prosessuelle stilling i straffesaker, jfr. Betænkning om forurettedes processuelle retsstilling i straffesager, Betænkning nr. 1485/2006.

10. Alle de nordiske landene har innført ordningen med bistandsadvokat til utvalgte grupper av fornærmede. Danmark var det første nordiske landet som innførte ordningen - i 1980, og Island det siste - i 1999.

11. Straffeprosessloven $\S 107$ a gir rett til bistandsadvokat for mishandling i nære relasjoner, og fornærmede i de fleste typer sedelighetssaker, herunder voldtekt og seksuelle overgrep mot barn. I tillegg kjønnslemlestelse, tvangsekteskap, brudd på besøksforbud og menneskehandel. Retten kan også oppnevne bistandsadvokat i andre tilfeller der sakens art og alvor tilsier det (strprl. $§ 107$ a tredje ledd).

12. Et utvalgsmedlem - som hovedsakelig arbeider som forsvarer - dissenterte.

13. Plasshensyn gjør det ikke mulig å forfølge dette videre teoretisk her, men det ligger spennende muligheter i å analysere endringene i sammenheng med endrede subjektposisjoner det senmoderne, jfr. f.eks. Rose 1999, Foucault 2002. 
14. Slik fornærmede altså har i Sverige og Finland. Her har fornærmede mulighet til å oppnå partsstilling i straffesaken med fulle partsrettigheter. Dette innebærer bl.a. rett til «... å ta ut egen tiltale, til å føre egne bevis og stille spørsmål under hovedforhandlingen til tiltalte, vitner og andre, rett til å prosedere og nedlegge påstand og til å anke over avgjørelser i straffesaken.» (Ot.prp. nr. 11 2007-2008, s. 16).

15. Det kan være grunn til å nevne at også det såkalte Kvinnevoldsutvalget inntok et slikt standpunkt. Slik utvalget så det verken kunne eller burde straff gjøres til «... det enkelte offers behov for å straffe gjerningsmannen, det må være overordnede samfunnsmessige grunner som gjør at samfunnet bruker straff. Dette bør gjenspeiles i reglene på den måten at det er staten - påtalemyndigheten - som forbeholdes retten til å uttale seg om bruk av straff.» (NOU 2003:31, s. 159-160).

16. Den såkalte familievoldsbestemmelsen, dvs. forbudet mot mishandling i nære relasjoner. Bestemmelsen ble vedtatt i 2005, og innført som $\S 219$ i straffeloven av 1902, og videreført som $\S \S 282$ og 283 i straffeloven av 2005 (§ 282 rammer mishandling og $\S 283$ grov mishandling). Bestemmelsen ble opprinnelig foreslått innført av Kvinnevoldsutvalget i 2003 etter inspirasjon fra den svenske bestemmelsen om Kvinnofridsbrott (NOU 2003:31).

17. Men det er også grunn til å understreke at en henleggelse ikke nødvendigvis er negativt for fornærmede. Men det som er viktig er at fornærmede får en forklaring på henleggelsen, framheves av flere. En bistandsadvokat sier: «Med en forklaring er det lettere for fornærmede å akseptere henleggelsen, mange skjønner at bevisene ikke er sterke nok. Det er også mange fornærmede som ønsker henleggelse, de ønsker ikke gjerningsmannen straffet. De har sett det positive i at utøver har blitt tatt inn til avhør, at det har blitt gjort noe med saken.»

18. Ikke så å forstå at slik deltakelse nødvendigvis fører til det. F.eks. er det vist i Fornærmedeutvalgets utredning at i Finland, der fornærmede har fulle partsrettigheter, er det veldig sjelden at fornærmede anker over straffeutmålingen.

19. F.eks. var det kun $23 \%$ av beboerne på krisesentrene i 2014 som hadde anmeldt forholdet. For flertallet av de som ikke hadde anmeldt, var det fordi de ikke ønsket (64\%). (Rapportering fra krisesentertilbudene 2014).

\section{Litteratur}

Aubert, Vilhelm (1979): Om straffens sosiale funksjon. Universitetsforlaget, 3. opplag.

Bakketeig, Elisiv og Jane Dullum (forthcoming): «Legal strategies and domestic violence.»

Bennett Cattaneo, Lauren and Lisa Goodman (2010): "Through the Lens of Therapeutic Jurisprudence. The Relationship Between Empowerment in the Court System and Well-Being for Intimate Partner Violence Victims." I: Journal of Interpersonal Violence, Vol 25 No 3, March 2010 482-502.

Ericsson, Kjersti (2003): «Kvinner som handlende offer.» I: Nordisk Tidsskrift for Kriminalvidenskab, Maj 1993, 80. årgang. Nr. 2

Foucault, Michel (2002): Forelesninger om regjering og styringskunst. Oslo: Cappelen Akademisk Forlag.

Garland, David (2001): The Culture of Control. Crime and Social Order in Contemporary Society. Oxford University Press.

Grøvdal, Yngvil (2012): «En vellykket sak? Kvinner utsatt for mishandling møter strafferettsapparatet.» $P h D$-avhandling, Institutt for kriminologi og rettssosiologi 
Hauge, Ragnar (2002): “Straffelovgivningens utvikling gjennom 100 år.” I: Tidsskrift for strafferett, 2002-4, s. 338-344.

Herman, Judith Lewis (2005): «Justice from the Victim's Perspective.» I: Violence Against Women, Vol. 11 No.5, May 2005, p. 571-602.

Høigård, Cecilie (1993): «The victim as expert: active and captive.» I: NORA, Vol. 1 (1993), Iss. 1.

Johnsen, Jon T. (2003): «Upartisk straffeforfølgning - ramme for fornærmedes rettigheter i straffesaker?» I: Tidsskrift for strafferett 2003-2

Merton, Robert (1949): Social Theory and Social Structure. New York: Free Press

Nielsen, Beth Grothe og Annika Snare (1998): Viktimologi. Om forbrydelsens ofre: teori og praksis. Århus: Aarhus Universitetsforlag.

NOU 1992:16 Sterkere vern og økt støtte for kriminalitetsofre. Oslo: Statens forvaltningstjeneste

NOU 2003:31: Retten til et liv uten vold. Menns vold mot kvinner i nære relasjoner. Oslo: Statens forvaltningstjeneste

NOU 2006:10 Fornærmede i straffeprosessen - nytt perspektiv og nye rettigheter. Oslo: Statens forvaltningstjeneste.

Ot.prp.nr. 11 (2007-2008) Om lov om endringer i straffeprosessloven m.v. (styrket stilling for fornærmede og etterlatte.

«Rapportering fra krisesentertilbudene 2014.» Barne- ungdoms- og familiedirektoratet.

Robberstad, Anne (2002): Kontradiksjon og verdighet. Komparativ fremstilling av fornoermedes stilling $i$ de nordiske land, med sikte på forslag om styrking av forncermedes rettigheter $i$ straffeprosessen. Rapport.

Robberstad, Anne (2003): Bistandsadvokaten: Ofrenes stilling i straffesaker. Oslo: Universitetsforlaget, 2. utgave.

Rose, Nikolas (1999): Powers of Freedom. Reframing Political Though. Cambridge University Press.

Skjørten, Kristin (2002): Lov og rett mot familievold? Oslo: Pax Forlag.

Stang Dahl, Tove (1994): Pene piker haiker ikke. Artikler om kvinnerett, strafferett og velferdsstat. Oslo: Universitetsforlaget.

Tham, Henrik (2002): “Brottsoffrets uppkomst og framtid.” I: Malin Åkerström \& Ingrid Sahlin (red.): Det motspänstiga offret. Lund: Studentlitteratur

Thoresen, Siri og Ole Kristian Hjemdal (red.) (2014): «Vold og voldtekt i Norge. En nasjonal forekomststudie av vold i et livsløpsperspektiv.» Nasjonalt kunnskapssenter om vold og traumatisk stress: Rapport 1/2014.

Ugelvik, Thomas og Jane Dullum (eds.) (2012): Penal Exceptionalism? Nordic prison policy and practice. London and New York: Routledge.

Wemmers, Jo-Anne (2009): «Where do they belong? Giving victims a place in the criminal justice process.» I: Criminal Law Forum, 20: 395-416

Zedner, Lucia (2004): Criminal Justice. Oxford University Press.

Aas, Geir (2014): Politiet og familievolden. Oslo: Universitetsforlaget

Aas, Geir (2013). «Politi- og påtalemyndighetens praktisering av familievoldsbestemmelsen (jfr. straffelovens § 219). Tidsskrift for strafferett, 13(2), 236-245. 